\title{
Offshore Export of Shelf Production in the Cape Blanc (Mauritania) Giant Filament as Derived From Coastal Zone Color Scanner Imagery
}

\author{
Albert J. Gabric,: Luis Garcia, Lieve Van Camp, Leo Nykjaer, \\ WALTER EIFLER, AND WOLFRAM SCHRIMPF
}

Institute for Remore Sensing Applications, Jnint Research Centre, Ispra, Ilaly

\begin{abstract}
Particulate organic carbon flux from the shelf to oceanic waters during upwelling between $19^{\circ} \mathrm{N}$ and $25^{\circ} \mathrm{N}$ off Mauritania has been analyzed using coastal zone color scanner (CZCS) imagery. Biomass in: the giant filament has been estimated using surface pigment concentration registered by CZCS during time series in December 1983, March 1984, and October 1984. Evidence for active phytoplankton growth ir: offshore waters is presented. Formation of the giant filament seems to be favored by the combination of a number of factors perhaps unique to the Mauritanian shelf. The large-scale circliation patterns promote oftshore advection, and the typically long period of wind forcing can move the upwelling center to the shelf break area, thus causing maximal phytoplankton growth rate to be achieved in oceanic waters. The relatively high pigment concentrations registered by CZCS in oceanic waters suggest that nutrients have not been depleted on the shelr and that in situ growth is occurring in deep waters. We have used a barociinic, hydrodynamic model to estimate cross-slope flux of particulate organic carbon at the $200-\mathrm{m}$ isobath and derive a mean value of aboui $1 \times 10^{5} \mathrm{~g} \mathrm{C} \mathrm{s}^{-1}$ during each of the CZCS time series.
\end{abstract}

\section{INTRODUCTION}

Biological export of carbon fixed during photosynthesis on continental shelves has been suggested as a major sink for the global carbon cycle [Deuser, 1979; Walsh ei al., 1981; Walsh, 1983, 1989] although the general applicability of this hypothesis has been questioned [Rowe et al., 1986; Falkowski et al., 1988]. Compared with other continental shelf ecosystems, upwelling zones are distinguished by a high input of "new" nutrients and subsequent relatively high fertility. Because of this high fertility the quantity of organic material that can be exported from upwelling areas through loss to shelf sediments $[D . J$. Smith el al., 1983] or adjacent deep waters, or as a fishery yield, is 10 to 100 times higher than other ecosystems can support [Barber and Smith, 1981].

Major coastal upwelling zones occur along eastern oceanic boundaries where large-scale weather patterns produce consistent longshore wind stress inducing Ekman transport of surface waters offshore. The cooler, usually nutrient-rich oceanic waters which are upwelled onto the continental shelf to replace the surface waters promote high local primary production. In contrast to other coastal and oceanic ecosystems, which may be limited to a single major productivity event per year, the period and rate of primary production are significantly greater in upwelling zones. Continental shelves where upwelling occurs are thus potentially important sites for conversion of dissolved inorganic carbon (in the newly upwelled waters as wel! as "old" shelf waters) to particulate organic form and export from the water column either to the

\footnotetext{
'Permenently at Faculy of Environmental Sciences, Griffith University, Nathan, Queensland, Australia.

Copyright 1993 by the American Geophysical Union.

Paper number 93JC01714.

$0148-0227 / 93 / 92 \mathrm{JC}-01714 \$ 05.00$
}

shelf sediment, continental slope, or, by adyection and settling processes, beneath the ocean thermocline [Wollast, 1990; McClain et al., 1986]. This last pathway, the so called biological pump, may be critical to the dynamics of climate change on the time scale of decades [Longhurst and Harrison, 1989],

Recently, Bakun [1990] has reported climate-changerelated intensification of coastal upwelling in several different regions which, by increasing primary production and carbon export, may provide an important negative feedback mechanism for the anthropogenic increase in atmospheric $\mathrm{CO}_{2}$. In the context of the global carbon cycle it is necessary to identify such regional sinks in order to quantify the atmosphere-to-ocean carbon flux on a global basis. The northwest African continental shelf is one of the major coastal upwelling regions and has been the subject of intensive field studies, e.g., Cooperative Investigation of the Northern Part of the Eastern Centra! Atlantic (CINECA) [Hempel, 1982] and JOINT I [Huntsman and Barber, 1977]. The shelf between $19^{\circ} \mathrm{N}$ and $24^{\circ} \mathrm{N}$, between Cape Timiris and Dakhla and including Cape Blanc, experiences conditions favorable for upwelling throughout the year 'Wooster et al., 1976]. Since upwellirig is fairly constant, with maximum intensity during spring and autumn, it is ikely that the Cape Blanc area is a prime site for export of she'f particulate organic carbon (POC) to the deep ocean.

In this paper we present an analysis of three distinct upwelling episodes recorded in Nimbus 7 coastal zone color scanner (CZCS) pigment concentration fields during December 1983, March 1984, and October 1984 ir: the Mauritanian upwelling zone. The aim here is to use the CZCS satellite imagery to measure the biomass that has been advected off the continental shelf and examine its temporal evolution during the upwelling event. By deriving an estimate of the flux of detrital organic carbon to sediments and deep waters we discuss the region's significance as a sink for atmospheric carbon. 


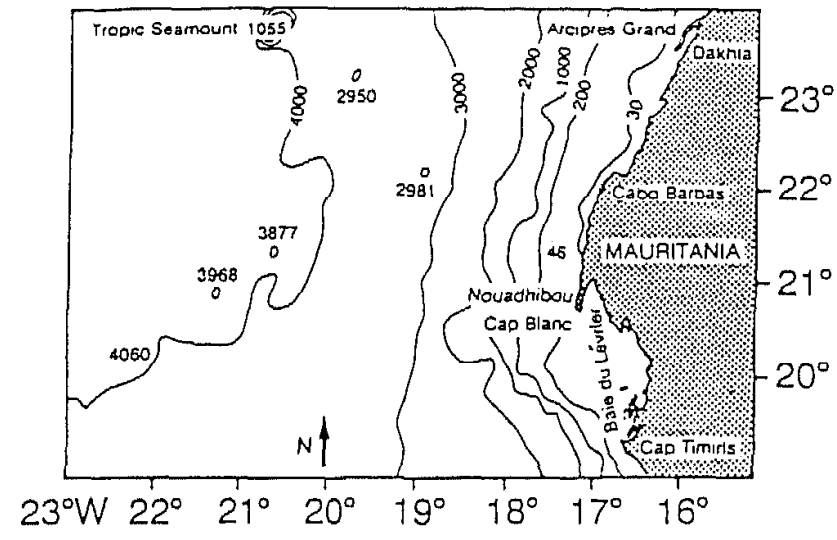

Fig. 1. Location of the study window off Mauritania.

\section{Characteristics of the Study Area}

\section{Physical Dynamics}

The geographical limits of the study window coincide approximately with the meridional and zonal extent (as detected in CZCS imagery) of the giant pigment filament at $19^{\circ}-24^{\circ} \mathrm{N}$ and $16^{\circ}-23^{\circ} \mathrm{W}$ (see Figure 1 ). This region includes the shelf between Dakhla to the north and Cape Timiris to the south and oceanic water up to $600 \mathrm{~km}$ offshore. The continental shelf varies in width from $32 \mathrm{~km}$ in the south to over $100 \mathrm{~km}$ in the northern part of the region. As defined by the $200-\mathrm{m}$ isobath, the continental shelf area in the study window is approximately $70,000 \mathrm{~km}^{2}$. Long-term wind data records on the coast at Nouadhibou $\left(21^{\circ} \mathrm{N}, 17^{\circ} \mathrm{W}\right)$ for the period 1972-1979, suggest steady, strong longshore winds with periods of 5-10 days, separated by shorter relaxation periods. Wind speeds varied from about $5 \mathrm{~m} \mathrm{~s}^{-1}$ in the winter months to around $10 \mathrm{~m} \mathrm{~s}^{-1}$ in spring and summer [Kirk and Speth, 1985].

The dynamic features of upwelling in the Cape Blanc area have been described by Mittelstaedt et al. [1975] and Huyer [1976]. Under favorable wind conditions the main characteristics are an equatorward coastal jet at the surface, quasibarotropic fluctuations in the longshore flow, and compensatory surface and subsurface poleward countercurrents. The shelf is shallow with a sharp shelf break (at $\sim 100 \mathrm{~m}$ ) and the slope is steep, with the consequence that the subsurface poleward undercurrent is confined to the slope below $200-\mathrm{m}$ depth. This is an important factor enabling offshore transport because the undercurrent cannot trap nutrient-rich water. which would be possible were it present on the shelf as occurs off Peru [Barber and Smith, 1981]. Surface poleward flowing countercurrents are a typical feature along the continental slope between $17^{\circ} \mathrm{N}$ and $23^{\circ} \mathrm{N}$, especially during winter and autumn. The existence of the surface countercurrent offshore implies a zone of intense shear in the alongshore current on the outer shelf with the potential for strong turbulent mixing in the longshore direction.

The cross-shelf circulation is well correlated with the wind forcing, with a time lag of about a day, and consists of offshore flow from the surface to $30-40 \mathrm{~m}$ and onshore flow in the lower part of the water column over the shelf and extending to a depth of $200 \mathrm{~m}$ on the slope. Isopycnals that slope upward toward the coast are indicative of upwelling. and off northwest Africa such slopes have been observed as far as $80 \mathrm{~km}$ offshore and to a depth of $200 \mathrm{~m}$ [Barton et al., 1975]. The stratification over the shelf is weak, corresponding to strong vertical mixing, with the mixed layer frequently reaching the bottom on the inner shelf.

The source waters for the upwelling are either North Atlantic Central Water (NACW) or the less saline, warmer South Atlantic Central Water (SACW) [Tomczak, 1982]. In the vicinity of Cape Blanc a complex mesoscale regime pertains since the area is a frontal zone between NACW and the more nutrient-rich, lower-density SACW, causing the circulation to be infuenced by thermohaline mixing processes [Barton, 1987]. The upwelled waters near Cape Blanc will thus vary in nutrient concentration depending on their origin, although the poleward transport of SACW by the undercurrent on the slope will tend to smear out the meridional nutrient gradient [Minas et al., 1982a].

Figure 2 shows the large-scale near-surface circulation off northwest Africa as described by Mittelstaedt $[1982,1991]$. Between $25^{\circ} \mathrm{N}$ and $21^{\circ} \mathrm{N}$ the Canary Current detaches from the continental slope and flows southwest, entraining shelf water from the north and south offshore. South of Cape Blanc there is a persistent mesoscale cyclonic gyre between $15^{\circ} \mathrm{N}$ and $21^{\circ} \mathrm{N}$ whose position varies with the season, being furthest north in winter and autumn. The location of the gyre can be an important factor in enhancing zonal offshore advection. As a result of the offshore advection of shelf water, which is usually rich in phytoplankton (and possibly nitrate), an extensive pigment plume is formed which was first described from analysis of CZCS data by Van Camp et al. [1991] and called the "giant filament."

Another factor influencing offshore export of phytoplankton and upwelled nutrients is the cross-shelf location of the upwelling center, where lowest water temperature, maximum vertical velocities, and highesl nitrate concentrations occur. The presence of cold water at the shelf break off Cape Blanc was recorded in the data presented by Meincke et al. [1975]. Barton et al. [1977] noted that in the Cape Blanc area the upwelling center migrates seaward at a speed of $4-5 \mathrm{~km}$ $\mathrm{d}^{-1}$ during an upwelling event. After $4-6$ days of persistent wind forcing the center reaches the shelf break and remains there until relaxation of the wind. Such long periods of persistent winds followed by shorter periods of relaxation are typical off northwest Africa. The implication here is that low-frequency wind forcing, leading to seaward displacement of the upwelling center, will favor the formation of a giant filament extending offshore.

\section{Biological Dynamics}

There are a number of factors, both physical and biological, that combine to create complexity in the phytoplankton dynamics in coastal upwelling zones. The energetic physical conditions that pertain are certainly important in shaping the biological structure of these waters. It has been suggested that community composition [Malone, 1975] as well as total biomass [Wroblewsti, 1977; $H^{\prime}, O$. Smith et al., 1983] are largely a result of the advective processes, namely the bilayer cross-shelf flow and wind-driven vertical mixing. For example. small-celled species with low sinking rates are likely to be selectively removed by offshore transport, while larger species which sink faster may be reentrained in the onshore flow and returned to the shelf. This has been called the conveyor belt model " by Hilkerson and Dugdale' [1987]. 

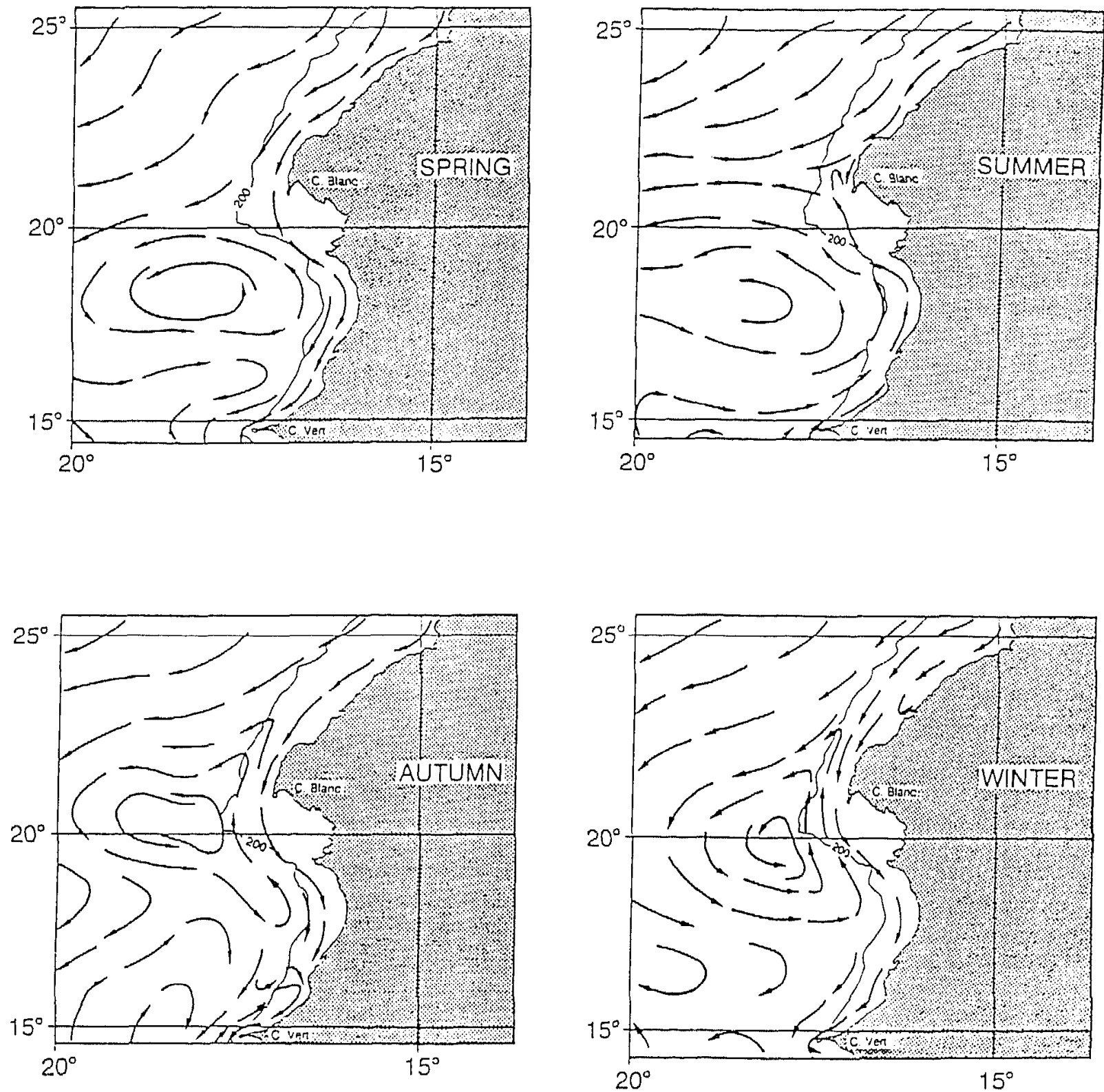

Fig. 2. Seasonal variability in large-scale near-surface circulation in the study window (adapted from Mittelstacdt [1991]): spring, April-May; summer, July-September; autumn, October-December; winter, Jantary-March.

The physiological state of phytoplankton is important in determining their nutrient uptake rate once in the surface Ekman flow. This was clearly demonstrated in the productivity measurements reported by Huntsman and Barber [1977], who found carbon fixation rates that almost doubled from the inner to the outer shelf region. Phytoplankton seeding of the shelf may occur from cells in the upwelled oceanic waters or from cells remaining on the shelf from a previous upwelling event [Jones and Brink. 1985]. When the seed cells originate from below the euphotic zone, they will need time to adapt their nutrient uptake rates to the higher illumination regime before adjusting their metabolism to a "shifted-up state" with increased growth rate [W'ilkerson and Dugdale, 1987].

Off Cape Blanc the strength of the wind often causes the mixed layer to be deeper than the euphotic zone and light limitation of production. In this area, maximum productivity rates are achieved only during periods of wind relaxation and weaker vertical mixing when the mixed layer depth is reduced [Dugdale and Wilkerson, 1985]. Another important point for the biological conditioning of the upwelled algal cells is the depth of the offshore flowing layer with respect to the euphotic depth. If the cells in the onshore flow experience enough illumination to become preconditioned to a higher light regime, then the subsequent nitrate uptake rates will be greater and shift-up will be accelerated. Clearly this will not be the case during shelf break upwelling when the seed cells originate from below the euphotic layer and are quickly advected to the surface offshore flowing layer, presumably still in a shifted-down state. This suggests that there may often be in situ phytoplankton growth in offshore oceanic waters (provided nitrate is not limiting) contributing to the maintenance of the giant filament. This hypothesis is supported by the satellite data record [tan Camp et al., 
1991, Figure 11; McClain et al., 1990, Plate 1] which show's that relatively high pigment concentrations $\left(1-2 \mathrm{mg} \mathrm{m}^{-3}\right)$ occur at distances over $100 \mathrm{~km}$ beyond the shelf break.

\section{Sedimentary Processes}

Some indication of sedimentary processes in the Cape Blanc area can be gained from the field data collected by Lenz [1982] during early 1975 which have been summarized in Figure 3. Particulate organic matter (POM) samples were collected on the midshelf (location I), shelf break (location II) and lower slope (location III), along transects at $21^{\circ} 16^{\prime} \mathrm{N}$ and $22^{\circ} 41$ ' N. Unfortunately, no data were collected further offshore.

The distributions of chlorophyll $a$, particulate organic nitrogen (PON), and particulate organic carbon (POC) (Figures $3 a, 3 b$, and $3 c$ ) all display a similar trend in the upper layer ( $<20-m$ depth) with minimum concentration at the shelf break. At deeper sampling depths $(>40 \mathrm{~m})$ the trend is a gradual decrease in concentration offshore. At the $150-\mathrm{m}$ sampling depth (Figure $3 d$ ), the POC component (corresponding to phytodetrital particles) is still approximately $40 \%$ of its surface value, indicating an appreciable sinking flux. It has been postulated that a reseeding mechanism may exist [Malone, 1975; W. O. Smith et al, 1983] whereby some of this material might be entrained in the onshore Ekman flow (present at about $200-\mathrm{m}$ depth) and returned to the shelf, although such a process would operate mainly on the upper slope. The size distribution below the euphotic layer is dominated by small particles $(<55 \mu \mathrm{m}$ ) which constitute up to $90 \%$ of the total, indicating the importance of phytodetrital material (e.g., senescent algal cells, fecal pellets) in the sinking flux. Interestingly, the POM at the lower slope sampling stations had the highest chlorophyll concentration in the euphotic layer (Figure $3 a$ ), confirming the surface offshore advection and suggesting minimal zooplankton grazing in deep waters.

\section{Methods}

\section{Satellite Image Processing}

As a preliminary step to the selection of coastal zone color scanner data for our study window, the advanced very high resolution radiometer ( $A$ VHRR) global area coverage (GAC) archive $(4 \cdot \mathrm{km}$ pixel resolution) was searched for dates between 1981 and 1984 where the sea surface temperature (SST) demonstrated strong upwelling. Unfortunately, few high-resolution AVHRR data have been saved for our region during the time periods analyzed here (National Oceanic and Atmospheric Administration, personal communication). The selection criteria were a time series of reasonable length to enable the tracking of an upwelling episode and a significant zonal temperature difference between coastal and oceanic water [Wooster ef al., 1976]. Based on the analysis of field data by Speth and Detlefsen [1982], we have chosen a temperature deficit of $3^{\circ} \mathrm{C}$ or more as indicative of strong upwelling. Of the approximately 1000 images inspected, fewer than $30 \%$ were rated as usable data, mainly owing to excessive cloud cover or aerosol interference which can often be caused by the presence of aeolian dust from the Sahara. Evidence for strong upwelling was detected throughout the year. For the benefit of future researchers, the resulting time series from the AVHRR GAC archival search are shown in Table 1. The CZCS archive was then searched for images coincident in time with these periods of strong upwelling. The limited availability of CZCS data restricted the final data set to three time periods consisting of 17 images whose dates are shown in Table 2.

The radiometric sensitivity of the CZCS has declined over time, and since the sensitivity loss has increased over time it is important to account for this calibration drift when time series are to be analyzed. The absolute reflectance values were adjusted following the recommendations of Sturm [1983]. The data were atmospherically corrected according to the method of Andre and Morel [1991] based on the use of a reflectance model valid for case 1 waters, where the optical properties of the water column are largely determined by the phytoplankton population. The method is not applicable to the case 2 waters of the inner shelf, which are characterized by high levels of suspended particulate matter, or the shallow Banc d'Arguin area south of Cape Blanc [Bricaud et al., 1987]. The pigment algorithm used for determining chlorophyl concentration, also given by Andre and Morel [1991], is

$$
\begin{aligned}
& \log C_{\text {sat }}= 0.347-2.73 \log r_{13}+2.14\left[\log r_{13}\right]^{2} \\
&-2.04\left[\log r_{13}\right]^{3} \quad C_{\text {sat }}<2 \mathrm{mg} \mathrm{m}^{-3} \\
& \log C_{\text {sat }}=0.661-8.48 \log r_{23}+11.52\left[\log r_{23}\right]^{2} \\
&-88.38\left[\log r_{23}\right]^{3} \quad C_{\text {sat }}>2 \mathrm{mg} \mathrm{m}^{-3}
\end{aligned}
$$

where $r_{i j}$ is the ratio of diffuse reflectance in CZCS bands $i$ and $j$, and $C_{\text {sat }}$ is the pigment concentration in milligrams chlorophyll per cubic meter. The agreement between in situ chlorophyll measurements and predictions using this algorithm is estimated to be in the range $\pm 30-50 \%$ [Bricaud and Morel, 1987]. Pigment images were then resampled and mapped onto a standard Mercator projection using satellite ephemeris data. In order to improve the geometric correction, a polynomial transformation was applied to the geometrically corrected image using ground control points automatically derived by matching the image coastline against reference cartographic data. A positional accuracy of 1-2 pixels was achieved by this procedure.

The satellite derived pigment concentration $C_{\text {sat }}$ is actually an exponentially weighted vertical average of the upwelling irradiance over an optical penetration depth, $Z_{\text {opt }}$, given by Clark [1981] as

$$
C_{\text {sat }}=\left[\int_{0}^{z_{\text {opt }}} C(z) \exp (-k z) d z\right] /\left[\int_{0}^{z_{\text {opt }}} \exp (-k z) d z\right]
$$

where $C(z)$ is the actual biomass profile and $k$ is the total water extinction coefficient, which is wavelength dependent [Kishino, 1981]. The bio-optical algorithm (equations (1) and (2)) is based on the upwelled irradiance at 443,520 , and 550 $\mathrm{nm}$ at which wavelengths $Z_{\text {opt }}$ is approximately 20,20 , and 9 $\mathrm{m}$, respectively, under oligotrophic conditions. Since $Z_{\mathrm{opt}}$ is typically $20-30 \%$ of the euphotic zone depth $Z_{\mathrm{e}}$ in clear waters and $50 \%$ of $Z_{c}$ in eutrophic waters [Smith, 1981], a possible source of error occurs when the chlorophyll maximum is situated below $Z_{\text {opt }}$ and does not contribute to $C_{\text {sal }}$.

Off Cape Blanc, field measurements suggest that $Z_{e}$ is approximately $22 \mathrm{~m}$ in offshore waters [Dugdale el al., 1989]. Unfortunately, there have been no studies aimed at 

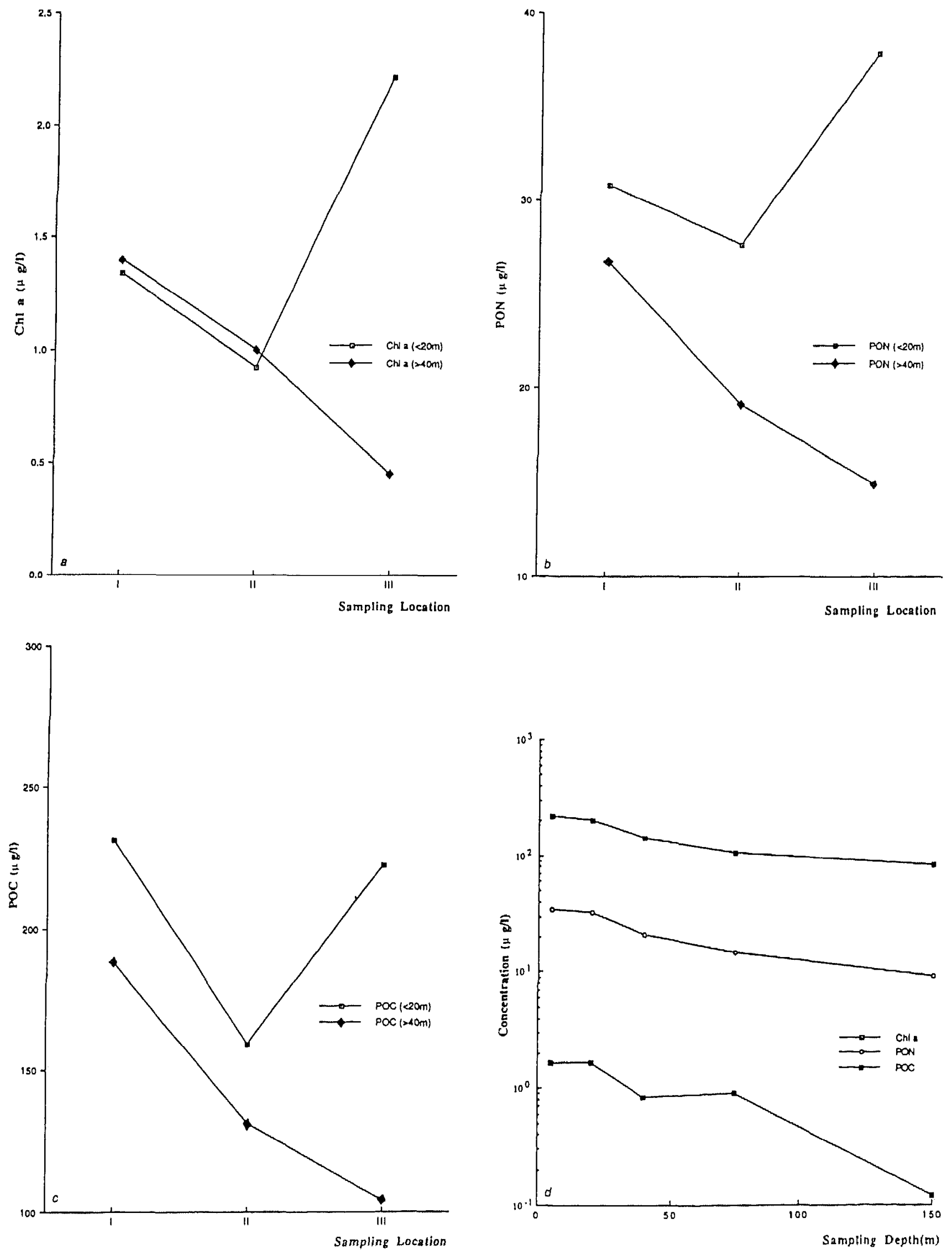

Fig. 3. The distribution of (a) chlorophyll $a,(b)$ particulate organic nitrogen (PON), and (c) particulate organic carbon (POC), off Cape Blanc, from Len: [1982] (I, midshelf; II, shelf break; III, lower slope), and (d) depth profles. 
TABLE 1. AVHRR-GAC Imagery Dates for Mauritanian Continental Shelf That Show Presence of Cold Water on Shelf

\begin{tabular}{cc}
\hline Period & $\begin{array}{c}\text { Meridional Extent } \\
\text { of Upwelling, }\end{array}$ \\
\hline $26.08 .1981-30.08 .1981$ & $23-32$ \\
$10.10 .1981-15.10 .1981$ & $23-25$ \\
$06.04 .1982-08.04 .1982$ & $20-24$ \\
$06.07 .1982-09.07 .1982$ & $20-32$ \\
$26.07 .1982-30.07 .1982$ & $20-28$ \\
$25.08 .1982-31.08 .1982$ & $21-28$ \\
$10.10 .1982-13.10 .1982$ & $30-32$ \\
$23.04 .1983-25.04 .1983$ & $18-26$ \\
$16.08 .1983-20.08 .1983$ & $21-32$ \\
$11.12 .1983-20.12 .1983$ & $20-24$ \\
$19.01 .1984-21.01 .1984$ & $16-26$ \\
$25.03 .1984-28.03 .1984$ & $21-26$ \\
$21.04 .1984-26.04 .1984$ & $16-22$ \\
$20.05 .1984-22.05 .1984$ & $17-24$ \\
$10.09 .1984-15.09 .1984$ & $20-26$ \\
$21.10 .1984-24.10 .1984$ & $20-32$ \\
\hline
\end{tabular}

*Read dates as day. month. year.

defining typical chlorophylf depth profiles in the oceanic waters of our study window, although the actual field data collected during CINECA suggest that over the first 20-30 $\mathrm{m}$, quasi-uniform profiles are the norm in the inshore region (see Figure $3 d$ ). Thus in order to estimate the depthintegrated chlorophyll over the whole of the euphotic zone, $C_{\mathrm{c}}$ (in milligrams chlorophyll per square meter), we use an empirical relationship given by Morel and Berthon [1989] derived from an extensive data base (over 3400 measurements; $r^{2}=0.87$ ) in low and moderate latitudes,

$$
C_{\mathrm{e}}=40.6\left[C_{\mathrm{sat}}\right]^{0.459}
$$

The total window biomass $B$ was derived by summing $C_{e}$ over all the usable pixels in each image.

\section{Wind Field Data}

Wind records for the 3 months containing our CZCS time series have been provided by a hindcast model of the European Centre for Medium-Range Weather Forecasts (ECMWF) at Reading, England. This model provides the wind field vector at $10-\mathrm{m}$ height, $\mathrm{U}_{10}$, with a horizontal resolution of 1.5 degrees in latitude and longitude, giving three data points within the study window. The wind stress vector $\tau\left(\mathrm{N} \mathrm{m}^{-2}\right)$ at the sea surface was derived using the conventional quadratic expression,

$$
\tau=\rho_{\mathrm{a}} c_{\mathrm{d}}\left|\mathrm{U}_{10}\right| \mathrm{U}_{10}
$$

where $\rho_{\mathrm{a}}$ is the density of air $\left(1.25 \mathrm{~kg} \mathrm{~m}^{-3}\right)$ and $c_{\mathrm{d}}$ the drag coefficient $(0.0014)$.

The Ekman transport vector $M_{e}$ (in kilograms per meter per second) can be estimated from the surface wind stress by

$$
M_{t}=(\tau \times k) / f
$$

where $\mathbf{k}$ is the unit vector in the vertical direction (positive upward), and $f$ is the Coriolis parameter, which is in the range (4.7-5.9) $\times 10^{-5} \mathrm{~s}^{-1}$ for the latitudes of our study window. The cross-shelf component of Ekman transport can be derived by rotating the local coordinate system at each of the wind data points to align with the coastline orientation and calculating the component of $\mathrm{M}_{\mathrm{c}}$ normal to the coastline. The Ekman volume transport vector $Q_{e}$ (in square meters per second), per unit width cross slope, may be computed from (6) by

$$
\mathrm{Q}_{\mathrm{e}}=\mathrm{M}_{\mathrm{e}} / \rho_{\mathrm{w}}
$$

with $\rho_{w}$ the density of water in the offshore flowing Ekman layer.

\section{Numerical Modeling}

\begin{tabular}{|c|c|c|c|c|c|}
\hline Orbit & Date* & $\begin{array}{l}\text { Biomass, } \\
\text { \& Chl } a \times 10^{9}\end{array}$ & $\begin{array}{c}\text { Mean } \\
\text { Concentration, } \\
\text { mg Chl m}\end{array}$ & $\begin{array}{c}\mathrm{POC} \\
\mathrm{gC} \times 10^{11}\end{array}$ & $\begin{array}{c}\text { Window } \\
\text { Coverage, } \\
\%\end{array}$ \\
\hline 25891 & 10.12 .1983 & 8.71 & 1.07 & 9.37 & 94 \\
\hline 26015 & 19.12 .1983 & 4.21 & 1.32 & 3.87 & 37 \\
\hline 26029 & 20.12 .1983 & 7.73 & $1.2 !$ & 7.58 & 74 \\
\hline 26098 & 25.12 .1983 & 4.22 & 1.44 & 3.64 & 34 \\
\hline 26112 & 26.12 .1983 & 6.92 & 1.18 & 6.92 & 68 \\
\hline 27204 & 14.03 .1984 & 5.57 & 1.35 & 5.04 & 48 \\
\hline 27218 & 15.03 .1984 & 5.37 & 1.38 & 4.76 & 45 \\
\hline 27232 & 16.03 .1984 & 7.09 & 1.39 & 6.26 & 59 \\
\hline 27273 & 19.03 .1984 & 8.26 & 1.39 & 7.31 & 69 \\
\hline 27287 & 20.03 .1984 & 7.39 & 1.30 & 6.87 & 66 \\
\hline 27301 & 21.03 .1984 & 7.50 & 1.30 & 6.98 & 67 \\
\hline 27356 & 25.03 .1984 & 2.94 & 1.18 & 2.95 & 29 \\
\hline 30176 & $15,10.1984$ & 7.43 & 1.10 & 7.82 & 78 \\
\hline 30190 & 16.10 .1984 & 4.33 & 0.97 & 5.07 & 52 \\
\hline 30259 & 21.10 .1984 & 5.12 & 1.10 & 5.41 & 54 \\
\hline 30273 & 22.10 .1984 & 5.92 & 1.30 & 5.51 & 53 \\
\hline 30342 & 27.10 .1984 & 7.11 & 1.10 & 7.52 & 75 \\
\hline
\end{tabular}

The Ekman formula (6) is a reasonable approximation for an infinite depth, barotropic ocean and steady wind forcing.

TABLE 2. CZCS Estimate of Biomass for the Study Window (Excluding Continental Sheln)

* Read dates as day. month. year.

tPercentage of the study window for which useable pixel data were available. 


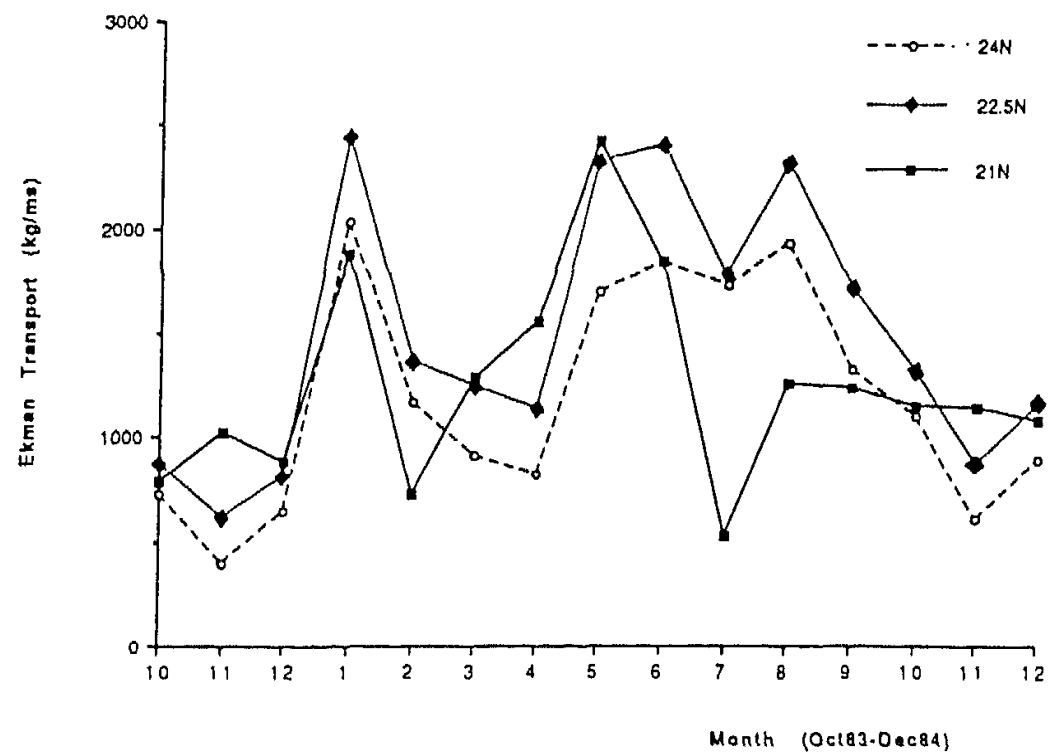

Fig. 4. Temporal variation in mean monthly cross-shelf Ekman transport at three locations in the study window.

However it does not take into account the effects of wind periodicity, varying shelf topography and water column stratification. In order to obtain an improved estimate of $Q_{e}$, we have used a three-dimensional, baroclinic hydrodynamic model [Eifler et al., 1991] to compute the cross-shelf velocity profile $\nu(z)$ normal to the $200-\mathrm{m}$ isobath. The model formulation is based on the primitive equations, the hydrostatic approximation, and the Boussinesq assumption with respect to the effect of variable density. Baroclinic effects have been computed using separate transport equations for heat and salinity. Transport of heat and salinity is computed using the turbulent kinetic energy profile predicted from the momentum equations and a depth-dependent mixing length.

The model was forced by the daily wind field for December 1983, March 1984, and October 1984. According to model simulations, a theoretical Ekman spiral rarely develops on the shelf, and thus it is difficult to define an Ekman depth. Consequently, model predictions for $\nu(z)$ were integrated over the predicted mixed layer depth $Z_{\mathrm{m}}$ to estimate the het cross-slope volume transport $Q_{n}$ (in square meters per second),

$$
Q_{\mathrm{n}}=\int_{0}^{Z_{\mathrm{m}}} \nu(z) d z
$$

Since the shelf orientation and width varies significantly in the study window, the computation has been made along cross-shelf sections at three latitudes $\left(21^{\circ} \mathrm{N}, 22.5^{\circ} \mathrm{N}\right.$, and $24^{\circ} \mathrm{N}$ ) corresponding to the location of the wind data points. Shelf topographies at these locations were digitized from bathymetric chart 837 of the Deutsches Hydrographisches Institut, Hamburg.

\section{RESULTS}

Monthly mean cross-shelf Ekman transport values for 1979 reported by $M C$ Clain et al. [1990] range from about 500 $\mathrm{kg} \mathrm{m}^{-1} \mathrm{~s}^{-1}$ in winter to over $2000 \mathrm{~kg} \mathrm{~m}^{-1} \mathrm{~s}^{-1}$ in the spring and summer. Figure 4 shows the mean monthly Ekman transport, calculated from the theoretical Ekman formula
(6), at the three wind data points in the study window from October 1983 to December 1984. The values range from a minimum of $396 \mathrm{~kg} \mathrm{~m}^{-1} \mathrm{~s}^{-1}$ to a maximum of $2424 \mathrm{~kg} \mathrm{~m}^{-1}$ $\mathrm{s}^{-1}$, a range similar to that in 1979 . We note the temporal correlation in the magnitude of Ekman transport at the three locations between $21^{\circ} \mathrm{N}$ and $24^{\circ} \mathrm{N}$, which are separated by about $300 \mathrm{~km}$, suggesting that the direction of wind forcing is reasonably uniform. The meridional variation in Coriolis force would lead to a gradient in the Ekman transport, with the value at the northern station about $80 \%$ of that at the southern station.

Numerical model predictions for December 1983 (Figure 5a) suggest that Ekman transport was directed offshore for most of the month and intensified between December 10 and December 16 to values as high as $3200 \mathrm{~kg} \mathrm{~m}^{-1} \mathrm{~s}^{-1}$ on December 12 at $21^{\circ} \mathrm{N}$ indicative of strong upwelling. The wind relaxed for 45 days from December 21 , and the model predicts onshore flow at $24^{\circ} \mathrm{N}$ during this period. We also note the meridional gradient in Ekman transport, with peak values highest at $21^{\circ} \mathrm{N}$, which would cause a clockwise steering of material transported offshore. The numerical model of (8) generally predicts a greater range in Ekman transport values than does the theoretical formula of (6)-(7). This is probably because the theoretical formula does not take into account the inertia of the coastal system.

By contrast, the situation during March 1984 (Figure 5b) was more variable with little offshore transport during the first 10 days of the month. A short period of strong upwelling from March 13 to March 16 was followed by wind relaxation. On March 21, winds intensified with very strong upwelling $\left(3500-4000 \mathrm{~kg} \mathrm{~m}^{-1} \mathrm{~s}^{-1}\right)$, particularly in the north of the study window, which continued for the rest of the month.

October 1984 (Figure $5 c$ ) was characterized by moderate to strong Ekman transport for the first 10 days, with particularly high values at $21^{\circ} \mathrm{N}$ on October 7 . A period of relaxation followed until October 17 , when winds increased with moderate to strong offshore transport at all latitudes for the remainder of the month.

The biological dynamics registered in the CZCS time 

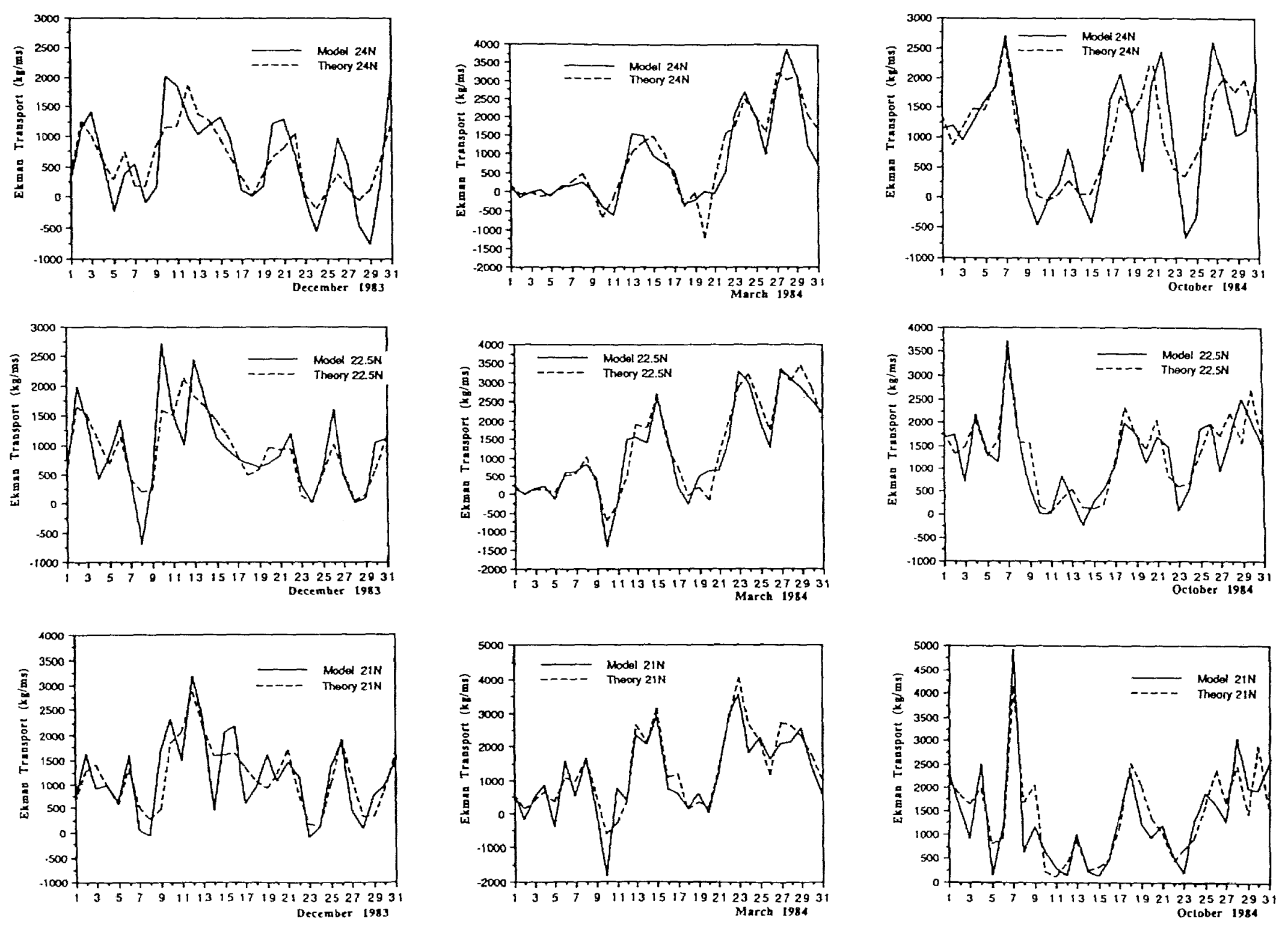

Fig. $5 a$

$$
\text { Fig. } 5 b
$$

Fig. Sc

Fig. 5. Numerical predictions and theoretical value of Ekman transport at $21^{\circ} \mathrm{N}, 22.5^{\circ} \mathrm{N}$ and $24^{\circ} \mathrm{N}$ for $(a)$ December $1983,(b)$ March 1984 , and (c) October 1984. Positive values indicate offshore transport. 
series, while closely coupled to the current physical dy namics of upwelling, will also be a function of the history of winc forcing immediately prior to data captire. As was noted above, long periods of corsistent wind forcing may shift the center of upwelling to the shelf break region and thus create the conditions for phytoplankion iranspon far offshore and possibly algal growth in oceanic waters, that is, formation of a giant flament. Evidence of shelf break upwelling in the Cape Blanc area is shown in the high-resolution AVHRR image of SST on February 27, 1987, presented by Van Camp et al. [1991] where there is a clcar decoupling of cold water in the slope region from that on the inner shelf between $21^{\circ} \mathrm{N}$ and $22^{\circ} \mathrm{N}$. Unfortunately, the low-resolution AVHRR data for our time periods makes it difficult to discern this effeci, although there is some evidence of coid water appearing on the slope in the GAC imagery on December 12 and December 18 .

The timing of the CZCS data capture (Table 2) succeeds a period of consistent, albeit weaker, upwelling. The persistent wind conditions during almost the entire month of December 1983 were conducive to the development of shelf break upwelling and distinguish this month from the other two when the CZCS time series succeeded a period of weak or variable winds. The AVHRR sea surface temperature record suggests that cold, upwelled water was already present on the shalf on December 5 .

Plate 1 shows the evolution of the pigment distribution from December 10 10 26, 1983. The December 10 scene is of high quality with minimal cloud cover in the study window. Because of the shallow depth and wind resuspension of sediment on the inner shelf, the high satellite pigment concentrations registered in this area correlate well with the $30-\mathrm{m}$ isobath and are probably not reliable. In fact, the field data record shows that because of high turbidity, algal productivity is limited by light on the inner shelf 1 Morel, 1982]. Further off shore, a relatively uniform tand of pigment with a concentration range of $0.7-1.5 \mathrm{mg} \mathrm{m}^{-3}$ extends from midshelf to be:ween $50 \mathrm{~km}$ and $100 \mathrm{~km}$ from the shelf break along the entire extent of the study window. Between $20^{\circ} \mathrm{N}$ anc $22^{\circ} \mathrm{N}$, offshore transport seems to be maximal with a filament extending first west and then north to a maximum distance of about $500 \mathrm{~km}$ offshore from the coast. A tongue of oligotrophic water between $22^{\circ} \mathrm{N}$ and $23.5^{\circ} \mathrm{N}$ separates the filament tip from the pigment closer to the shelf. Both these fcatures are preserved untii December 20, with some smearing of the oligotrophic tongue on December 25 consistent with a drop in Ekman flow just before this time. During autumn and winter the position of the cyclonic gyre (Figure 2) causes northerly transport in the slope region off Cape Blare which may be contributing to the filameni orientation.

lt is interesting to note that peak pigment concentrations of $1.5-2.0 \mathrm{mg} \mathrm{m}^{-3}$ occuring within the filament at distances of over $100 \mathrm{~km}$ from the shelf break are of the same magnitude as those on the outer shelf. If advection of waters from the shelf offshore were the only process operating, turbulent diffusion theory [Otmidor, 1990? would suggest a decline in the peak concentiation along the filament axis roughly propor:ional to the offshore distance traveled. The fact that neat concentrations hate not decreased is strong evidence for in situ growth of the phytoplanktor: in ofishore waters. This suggests that nu:rients are no: being exhausted on tha shell, at hypothesis consisteni with either low nutrient uprake rate on the shalf break upwelling. The December 19 scene cleariy shows pigment concentrations less than $0.5 \mathrm{mg}$ $\mathrm{m}^{-3}$ in the outer shelf while offshore peak concentrations of $1.5-2.0 \mathrm{mg} \mathrm{m}^{-3}$ still occur, lendirg further support to the suggestion that active phytoplankton growth is occurring in oceanic waters.

The March 1984 pigment time series is shown in Plate 2 and comes after abou: 10 days of weak or no upwelling. Cross-slope transport seems to be enhanced in the northern part of the window compared with December 1983. Although the offshore extent of the pigment distribution is comparable to the previous time series, the circulation pattern seems more complex and a weil-defined filament structure is not discernible. The cyclonic gyre moves south of Cape Blanc durirg spring (Figure 2) and has less infuence or offshore transport north of $20^{\circ} \mathrm{N}$. As in December 1983 the presence of comparatively high pigment concentration offshore from the siope is evident and suggests in situ growth. Intrusion of oligotrophic offshore water into the high-pigment zone is apparent in the images of March 19,20, and 21 at about $22^{\circ} \mathrm{N}$. Inspection of the corresponding AVHRR SST data indicates that this structure is warm water of offshore origin, and the dipole eddy shape confirms the direction of now' to be onshore coinciding with a period of wind relaxation. The zonal temoerature gradient increases with the onset of spring [Mintelsracdt, 1991] as offshore waters are heated, increasing the possibility of density driven circulation patterns.

The October 1984 CZCS time series (Plate 3) coincided with the onse: of upwelling after a period of 6 days of wind relaxation. The autumnal large-scale surface circulation pattcrn (Figure 2) resembles the winter situation, with the cyclonic gyre now positioned so as to enhance westerly transport of Cape Blanc. High-pigment streamers and oligotrophic intrusions are evidence of energetic mesoscale mixing offshore along the northern fronl of the pigment distribution in the October 15 image (Plate 3). Cross-slope expor: of shelf production in the north of the window between $23^{\circ} \mathrm{N}$ and $24^{\circ} \mathrm{N}$ seems reduced compared with the December and March time series, and the increase in offshore pigment between October 15 and 27 in this area is clearly documented in the imagery. Although partly obscured by cloud. a well-defined pigment filament is clear in the October 21 image which extends $400-500 \mathrm{~km}$ from the coast. Peak pigment concentrations are again high $(-1.5 \mathrm{mg}$ $\mathrm{m}^{-3}$ ) in oceanic waters. It is interesting to note the evidence for strong cyclonic advection in the gyre south of Cape Blanc where there is a marked change in the pigment distribution in decp waters between $19^{\circ} \mathrm{N} 1020^{\circ} \mathrm{N}$ from October 21 ic October 22, at period too brief to be explaired solely by in silu growiti.

We have calculated the biomass in the euphotic zone in the oceanic waters of the window by applying the chlorophyll algorithm given in (1)-(4) after masking out the shelf as defined by the $200-\mathrm{m}$ isobath. The resulting estimates are given in Table 2. Mean chlorophyll a concentrations in the offshore part of the window are high (>1 $\mathrm{mg} \mathrm{Chl} \mathrm{am}^{-3}$ ) and relatively constant during each time series. In order :o conven the bionass units from grams of chlorophyll a to grams of carhor. We have used the empirical relationship between jarticulate organic carbon and chlorophyll concentration derived during JOINT-I for the Cape Blane area [Huntsman ard Barber, 1977],

$$
\mathrm{POC}=91-23 \cdot \mathrm{Chl}
$$



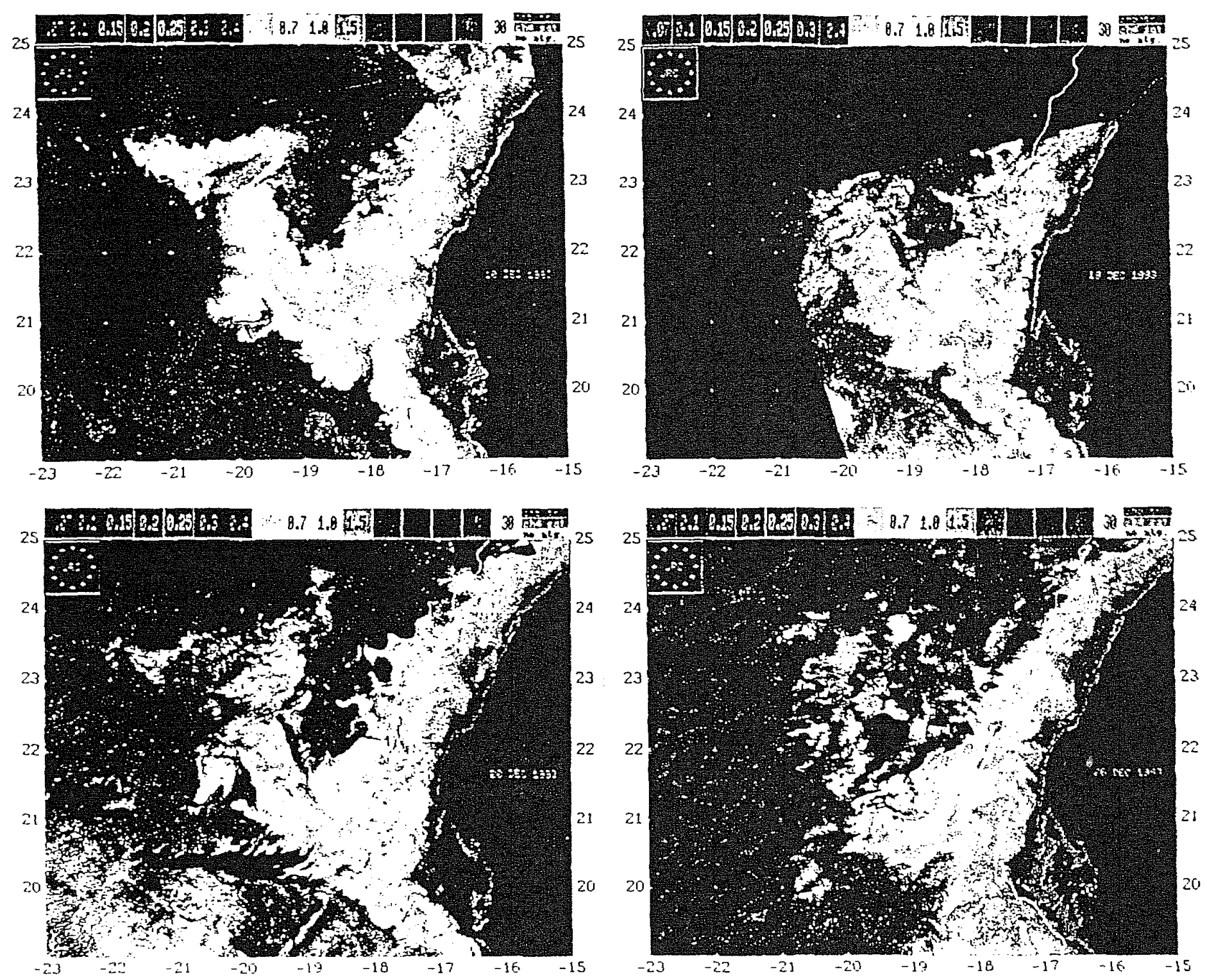

Plate 1. (ZCS time series for December 16), 19, 21), and 26, 1983. Chlorophyll-fike pigment concentrations are given in milligrams per meter. The legend gives the upper bound of the concentration range for each false color. White crosses indicate 1 degree of latilude or longitude $(-111) \mathrm{kml}$, and the $20 \mathrm{k}) \cdot \mathrm{m}$ isobath is overlaid in white. Black indicates land. 

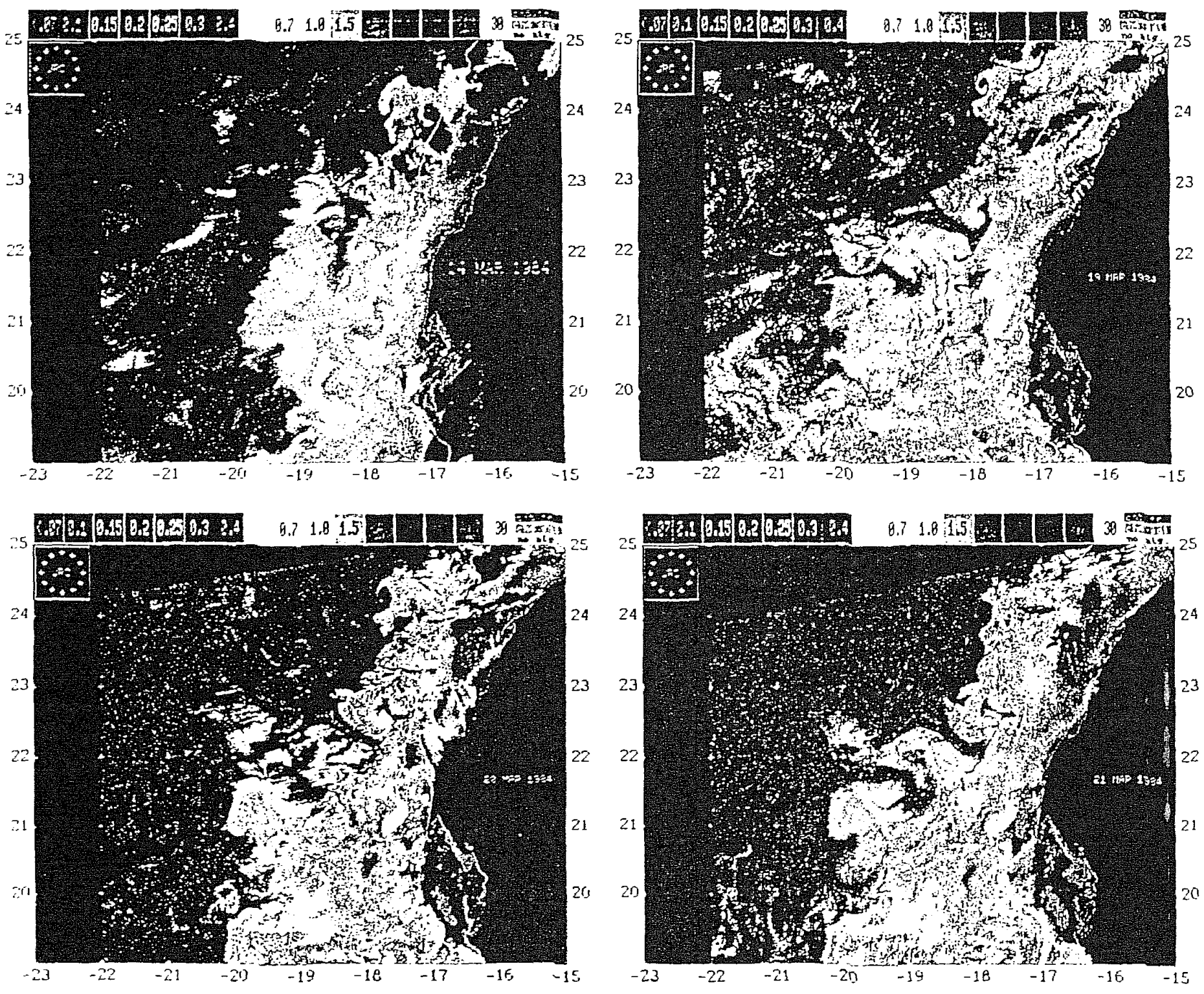

Plate 2. CZCS time series for March 14, 19, 20, and 21, 1984 , 

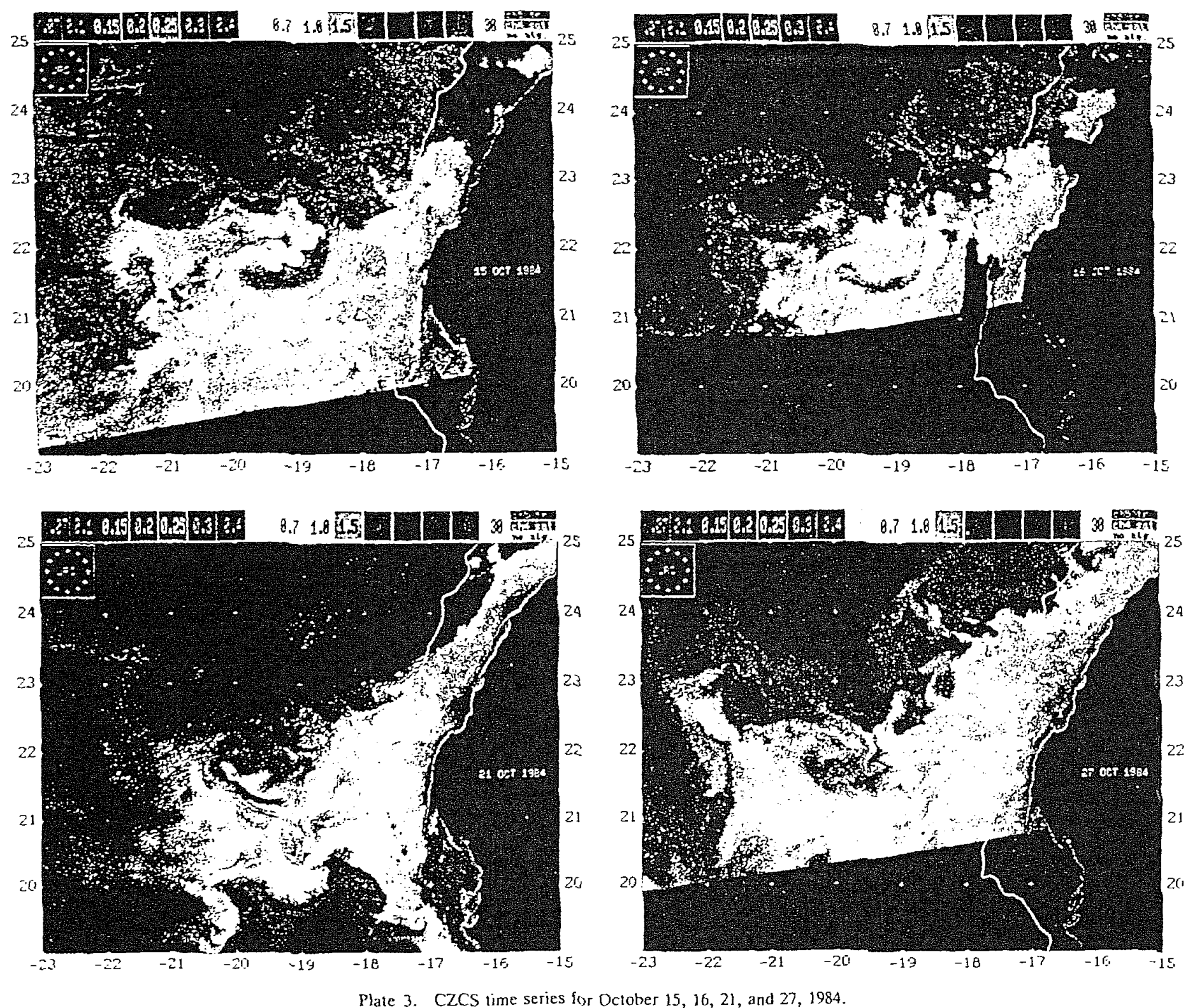
TABLE 3. Offshore Export of Particulate Organic Carbon Across the 200-m Isobath in the Study Window

\begin{tabular}{|c|c|c|c|c|c|c|}
\hline \multirow[b]{2}{*}{ Period* } & \multirow{2}{*}{$\begin{array}{c}C_{\text {sal }}, \\
\mathrm{mg} \mathrm{Chl} \mathrm{m}\end{array}$} & \multirow{2}{*}{$\begin{array}{c}\mathrm{POC} \\
\mathrm{mg} \mathrm{C} \mathrm{m}\end{array}$} & \multicolumn{3}{|c|}{$Q_{n}, m^{2} s^{-1}$} & \multirow{2}{*}{$\left(\mathrm{gCs}^{-{ }^{\prime}}\right) \times 10^{5}$} \\
\hline & & & $21^{\circ} \mathrm{N}$ & $22.5^{\circ} \mathrm{N}$ & $24^{\circ} \mathrm{N}$ & \\
\hline $10-26.10 .1983$ & 1.2 & 119 & 1.4 & 1.1 & 0.8 & 0.92 \\
\hline $14-25.03 .1984$ & 1.3 & 121 & 1.5 & 1.4 & 0.9 & 1.1 \\
\hline $15-27.10,1984$ & 1.1 & 116 & 1.1 & 1.2 & 1.0 & 0.90 \\
\hline
\end{tabular}

* Read dates as days. month. year.

tMean value.

with $P O C$ in milligrams $C$ per cubic meter and $\mathrm{Chl}$ in milligrams per cubic meter.

Variability in cloud cover and meridional data reception change the effective coverage from a minimum of $29 \%$ (March 25, 1984) to a maximum of $94 \%$ (December 10, 1983) of the total number of pixels in the masked window, making it difficult to follow the temporal evolution of the offshore pigment distribution. Because of the spatial heterogeneity of the pigment distribution it is not possible to simply scale up the biomass in each image according to the percentage of missing pixels. However, by a linear regression of biomass against window coverage, we can obtain an estimate of the correlation between these two variables and hence the temporal variability of total biomass with each time period. The results of this analysis suggest biomass is strongly linearly related to window coverage (December 1983, $r^{2}=$ 0.99; March 1984, $r^{2}=0.99$; October 1984, $r^{2}=0.98$ ) which implies biomass was approximately constant during each of the three time series. The change in total biomass $B$ can be formulated as

$$
d B / d t=(A-S)+(P-R-G)
$$

with $A$ the net horizontal advective flux of POC into the oceanic part of the window (assumed positive), $S$ the sedimentation below the euphotic zone, $P$ the productivity in oceanic waters, $R$ community respiration, and $G$ herbivore grazing. The mass balance given in (10) shows the interplay between advective and biological processes in determining the spatio-temporal biomass distribution. If $B$ is approximately constant during the time series, $d B / d t \cong 0$ and thus

$$
A+(P-R) \cong S+G
$$

Assuming approximately zonal horizontal transport and negligible horizontal flux across the offshore meridional boundary of the window, A may be estimated for each of the CZCS time series, from the cross-slope volume flux calculated at the $200-\mathrm{m}$ isobath,

$$
A \cong \int Q_{n} \cdot \operatorname{POC} d L
$$

where $Q_{n}$ is the time-averaged volume flux derived from (8) and POC is computed from the satellite derived mixed layer chlorophyll concentration in the slope region by examination of the imagery and by using (9). The integration is along the entire length $L$ of the $200 \mathrm{~m}$ isobath in the study window (approximately $700 \mathrm{~km}$ ). The results are shown in Table 3.

\section{DisCusSion}

An extensive series of field measurements along a transect at $21^{\circ} 40^{\prime} \mathrm{N}$ during the JOINT.I experiment indicate an average productivity of $2-3 \mathrm{~g} \mathrm{C} \mathrm{m}^{-2} \mathrm{~d}^{-1}$ in the mid to outer shelf region [Huntsman and Barber, 1977]. Winds were quite strong during most of JOINT-I, so that productivity would have been light-limited owing to a deep mixed layer; thus this estimate is likely to be less than the value that could be realized under more favorable conditions. In fact. Minas et al. [1982a] report values a high as 3.3 and $4.7 \mathrm{~g} \mathrm{C} \mathrm{m}^{-2} \mathrm{~d}^{-1}$ at some stations during the same period. Allowing for light limitation of productivity on the turbid inner shelf, we assume a mean annual value of $1 \mathrm{~g} \mathrm{C} \mathrm{m}^{2} \mathrm{~d}^{-1}$ and obtain an estimate of $2.5 \times 10^{13} \mathrm{~g} \mathrm{C} \mathrm{yr}^{-1}$ for the productivity of the continental shelf in our study window. Wollast [1990] has recently suggested a figure of $6.9 \times 10^{15} \mathrm{~g} \mathrm{C} \mathrm{yr}^{-1}$ for the annual primary production of global continental shelves. Thus to place the shelf region of the study window in perspective, it represents $0.2 \%$ of the total continental shelf surface area $\left(-3 \times 10^{7} \mathrm{~km}^{2}\right)$ and, not insignificantly, $0.36 \%$ of global shelf production.

Primary production associated with nitrate uptake has been termed "new" production by Dugdale and Goering [1967] to differentiate the utilization of allochthonous nitrog. enous nutrients (primarily from upwelling in the study window but also from riverine or atmospheric fluxes input of nutrients in other coastal regions) from regenerated production due to the assimilation of autochthonous nitrogen (mainly ammonium) produced by food web recycling. The ratio of new production to total primary production is known as the $f$ ratio [Eppley and Peterson, 1979] and can be formulated in terms of nitrogen biomass specific uptake rates $V_{N O}$ (nitrate) and $\mathrm{VNH}_{4}$ (ammonium) as

$$
f=V \mathrm{NO}_{3} /\left(V \mathrm{NO}_{3}+V \mathrm{NH}_{4}\right)
$$

The $f$ ratio for Cape Blanc region has been estimated variously as $52 \%$ during CINECA and $70 \%$ during JOINT-I [Codispoti et al., 1982], and as high as $90 \%$ by Minas et al. [1982b]. This high proportion of new production contrasts markedly with the estimate of $f$ in the open ocean of about $10 \%$ and is higher than the average for neritic waters of $46 \%$ [Eppley and Peterson, 1979]. If we conservatively assume an average value of 0.5 for $f$. then the new production for the shelf in our study window is estimated as $1.2 \times 10^{13} \mathrm{~g} \mathrm{C}$ $\mathrm{yr}^{-1}$. It is interesting to compare this with the estimate by Takahashi er al. [1986] of biological uptake (total produc- 
tion) of carbon for the whole North Atlantic basin between $10^{\circ}$ and $40^{\circ} \mathrm{N}$ (excluding the continental shelf) of $2.6 \times 10^{14}$ $\mathrm{gC} \mathrm{yr}^{-1}$

Walsh et al. [1981] argued that in general up to $50 \%$ of annual new production could be exported from continental shelves and deposited as phytodetrital particles on the slope or beyond in deeper waters. Falkowski ef al. [1988] have suggested that in some cases where density fronts impede cross-shelf mixing, export of shelf-derived production to the deep ocean can be as little as 10-20\%; however the satellite data indicate that such a situation does not apply in the Cape Blanc area. Dugdale et al. [1989, 1990] have used a shift-up model to estimate the time scale for attainment of maximum nitrate uptake rate, $V \mathrm{NO}_{3}$ (equivalent to new production) in the Cape Blanc region. Their results suggest that $V \mathrm{NO}_{3}$ reaches a maximum about 3 days after newly upwelled water reaches the surface layer in the upwelling center. However. as was noted above, the upwelling center itself migrates toward the shelf break during periods of low-frequency wind forcing; thus assuming a typical surface current of $0.3 \mathrm{~m} \mathrm{~s}^{-1}$, a cell in the surface layer would travel approximately $80 \mathrm{~km}$ from the upwelling center before attaining maximal uptake rate. The shelf width varies from $32 \mathrm{~km}$ in the south to over $100 \mathrm{~km}$ in the north of the study window. Thus maximum uptake rates are more likely to be achieved in offshore waters in the southern section than in the northern section, where maximum uptake will probably occur on the wider shelf. This hypothesis is supported by the satellite-derived chlorophyll distribution for December 1983 (Plate 1), when Ekman transport was offshore for the week prior to the imagery time series with conditions suitable for the migration of the upwelling center to the shelf break. The imagery clearly shows higher offshore pigment concentration in the southern section.

It is likely that in the Mauritanian upwelling region the percentage of new primary production exported from the shelf may be much higher than $50 \%$ given the unique combination of offshore Ekman transport and the large-scale offshore circulation patterns that pertain. Assuming that only half the new production is exported, and neglecting any further in situ net productivity, namely, $(P-R)=0$ in (11), a conservative estimate of the carbon exported offshore from the shelf in the study window is $6 \times 10^{12} \mathrm{~g} \mathrm{C} \mathrm{yr}^{-1}$ with an equal amount deposited on the shelf.

Our calculations for net offshore export (Table 3 ) are in a tight range of about $1 \times 10^{5} \mathrm{~g} \mathrm{C} \mathrm{s}^{-1}$, corresponding to an annual flux of about $3 \times 10^{12} \mathrm{~g} \mathrm{C} \mathrm{yr}^{-1}$. It is important to note, however, that the mean monthly Ekman transport data (Figure 4) suggest that December 1983, March 1984. and October 1984 were toward the lower end of the range of values realized during 1983-1984. Thus our results would seem to confirm the estimate of annual export $\left(6 \times 10^{12} \mathrm{~g} \mathrm{C}\right.$ $\mathrm{yr}^{-1}$ ) based on primary productivity arguments which was made above.

Legendre [1990] has noted that the ultimate fate of the POC produced during bloom events, where in situ recycling is small (as evidenced by a high $f$ ratio) and grazing pressure rather low, is sedimentation to the sea bed. During an upwelling episode on the Cape Blanc shelf, the measurements of $f$ suggest that nutrient recycling is indeed low and grazing pressure seems to decline across the shelf, as is evidenced by a marked decrease in zooplankton numbers in the offshore oceanic waters, particularly north of Cape Blanc
[Weikert, 1982]. Thus significant POC sedimentation may occur in the giant pigment offshore. The vertical flux of phytodetrital material in the ocean can be quite high ( $>100 \mathrm{~m}$ $\left.\mathrm{d}^{-1}\right)$ and seasonal deposition to the deep-sea foor $(4000 \mathrm{~m})$ has been observed following bloom events [Lampit, 1985]. Rapid mass sedimentation of phytoplankton cells (especially diatoms) has been widely observed following surface blooms and has been suggested by Smetacek [1985] to be a deliberate ecological strategy. Walsh [1983] has pointed out that this phenomenon may be a key process for sequestering carbon in the ocean. Of relevance to the Cape Blanc region is the predominance of the colony-forming diatom Thalassiosira partheneia, which can constitute up to a third of the local primary production [Elbrachter, 1982] and, because of its aggregative ability, can sink rapidly. A crucial question for the regional carbon balance is how much of this detrital POC escapes conversion to atmospheric $\mathrm{CO}_{2}$ on a time scale comparable to that of anthropogenic production.

The fraction of POC that is buried and preserved in the sediments escapes the ocean system and thus represents a sink for carbon on a geological time scale. Wollost [1990] has suggested that in areas where sedimentation rates are high, about $10 \%$ of the organic matter deposited at the sedimentwater interface is preserved. Seibold [1982] reported the sedimentation rate off northwest Africa as $0.005-0.01 \mathrm{~cm}$ $\mathrm{yr}^{-1}$; thus we estimate the amount preserved on the shelf as $6 \times 10^{11} \mathrm{~g} \mathrm{C} \mathrm{yr}^{-1}$.

Further offshore in deep waters, bacterial respiration of exported POC produces $\mathrm{CO}_{2}$ during sinking. However, as was pointed out by Wollast [1990], if this occurs below the thermocline, the carbon is effectively trapped as part of the dissolved inorganic carbon reservoir and may be considered a temporary sink (of order a few centuries) for the $C$ cycle. How much POC is respired above the thermocline? The answer to this question depends on factors such as the sinking rate of detrital particles in the water column and the heterorrophic bacterial population in the surface mixed layer [Ducklow' et al., 1986]. Measurements done by Martin et al. [1987] as part of the VERTEX studies in the northeast Pacific indicate that $50 \%$ of the organic carbon that sinks from the surface is respired at depths of less than $300 \mathrm{~m}$ and so can be recycled to the atmosphere on a short time scale. Thus assuming negligible grazing offshore within the giant pigment filament, $G \equiv 0$ in (11), and we estimate that $3 \times$ $10^{12} \mathrm{~g} \mathrm{C} \mathrm{yr}^{-1}$ is removed by sinking to the deep ocean.

In the Cape Blanc upwelling zone a number of physical and biological factors, namely, low-frequency wind forcing, large-scale circulation patterns, and physiological shift-up of nutrient uptake, combine to create conditions which are conducive to the development of a giant pigment filament which can extend hundreds of kilometers offshore. As a consequence, we suggest that this area plays a central role in the regional carbon cycle and that the offshore zone may be an important temporary sink that should be included in future carbon budget estimates of the North Allantic.

Acknowledgments. The CZCS raw data were supplied by ESA Earthnet. Frascti. laty and the wind field data were obtained from the European Centre for Medium-Range Weather Forecasts, Read. ing. LK. E. Mituelstued of the Deutsches Hydrographisches Institue. Hamburg, kindly provided information on the large-scale circu. lation patterns in the Cape Blanc region. This work was done while the first author was on leave at the Joint Research Centre. Ispra, and 
the financial support of the JRC Visiting Scientist Scheme is gratefully acknowledged.

\section{REFERENCES}

André, J, M., and A. Morel, Almospheric corrections and interpretation of marine radiances in CZCS imagery revisited, Oceanol. Acta, 14, 3-22, 1991.

Bakun, A., Global climate change and intensification of coastal upwelling. Science. 247, 198-201, 1990.

Barber. R. T., and R. L. Smith, Coastal upweiling systems, in Analysis of Marine Ecosysiems, edited by A. R. Longhurst, pp. 31-68. Academic. San Diego. Caiif.. 1981.

Barton. E. D.. Meanders. eddies and intrusions in the thermohaline front off nortinwest Africa, Occanol. Acta. 10, 267-283, 1987.

Barton. E. D., R. D. Pillsbury, and R. L. Smith, A compendium of physical observations from JOINT-1. Ref. 75-17,60 pp.. Sch. of Oceanogr.. Oreg. State Univ., Corvallis. 1975.

Barton, E. D., A. Huyer, and R. L. Smith. Temporal variation observed in the hydrographic regime near Cabo Corviero in the northwest African upwelling region. February to Aprii 1974. Deep Sea Res., 24, 7-23, 1977.

Bricaud. A., and A. Morel, Atmospheric corrections and interpretation of marine radiance in CZCS imagery: Use of a reflectance model. Occansl. Acra. 7. 33-50. 1987.

Bricaud, A.. A. Morel, and J. M. André. Spatial-temporal variability of algal biomass and potential productivity in the Mauritanian upwelling zore, as estimated from CZCS data, Adr. Space Res., 7(2), 253-26?. 1987

Clark. D. K., Phytoplankton pigment algorithms for the Nimbus-7 CZCS, in Oceanography From Space. edited by J. F. R. Gower, pp. 227-237, Plenum, New York 1981.

Codispoti. L. A., R. C. Dugdale, and H. J. Minas, A comparison of the nutrient regimes off northwest Africa, Peru and Baja Califor nia, Rapp. FV. Reun. Cons. Im. Explor. Mcr.. 180. 184-201 1982.

Deuser, W. G., Marine biota, nearshore sediments, and the globa! carbon balance, Org. Geochem.. 1, 24.3-247, 1979.

Ducklow, H. W., D. A. Purdie, P. J. LeB, Williams, and J. M. Davies. Bacterioplankton: A sink for carbon in a coastal marine plankion community. Science, 232, 856-867, 1986.

Dugdale, R. C., anc J. J. Goering, Uptake of new and regenerated forms of nitrogen in primary productivity. Limmol. Occanogr., 12, $196-206,1967$.

Dugdale, R. C.. and F. P. Wilkerson. Primary production in the Cape Blanc region. ir. International Sympositum on the Most Importam Upwelling Areas off Western Africa (Cape Blanco and Benguela). pp. 233-243. Instituto de Investigaciones P'esqueras. Barcelona. Spair. 1985.

Dugdale, R. C.. A. Morel. A. Bricaud, and F. P. Witkerson, Modeling new production in upwelling centers: A case study of modeling new production from remotely sensed temperature and color, J. Geophes. Re's. 94:C12), 18,119-18.132. 1989.

Dugdaie, R. C.. F. P. Wilkerson. and A. Morel. Realization of new production in coatstal upwelling areas: $A$ means to compare relative performince, Limmul. Ocetmogr. 35, 822-829, 1990

Eifler, W. T. Kupusovic, and $W^{\prime}$. Schrimp? Numerical verification exercises with different computer modeis for simulating sea circlatation pattern: The vertical diffuston of momentum ir: a Forced barotropic sea. Entiron. QHell. Lifo Re'p. EUR 13370 EN, Comm. of the Eur. Communities. 1991

Elbrachter. M. The distribution and ecological significance of the plankionic diatom Thalassiosirn partheneia. Rapp. P V. Reun. Cons. Im. Eiphr. Her.. 180. 24+245. 1982.

Eppley. R. W. and B. J. Peterson. Particulate organic matter flux and the planktonic new production in the deep ocean. N'ulure'. 282. 677-680, 1979

Falkowski. ?. G.. C. N'. Flagg. G. T. Rowe. S. L. Snith. T. E. Whitledge, and C. D. Wirick. The fate of a spring phytoplaniton boom: Export or oxidation. Com Shalf Re's. 8. 456-484. 1988.

Hempel. G. (Ed.l. The Canary Curten!: Stuclies of an upuelling system, Rapr. P'. Rum. Cans. In. Expler. Me'.. 180. $455 \mathrm{pp}$. 1982.

Hunstman. S. A., and R. T. Barber. Fr:mary groduction off northwest Africa: The relationship to wind and nutrient conditions. Deep Sea Re... 24. 25-34. 197\%
Hujer. A.. A comparison of upwelling $\mathrm{c}$ events in twn locations: Oregon and northwest Afriza, J. Mal, Res.. 34(4), 531-547, 1976. Joncs. B., and K. Brink. Mecharism of seecing phytoplarkton populations in coastal upwelling structures (abstract), Eos Trams. AGU, 66(51), 1259, 1985.

Kirk. A. and P. Speth. Winc corditions along the coast of north. west Africa and Portugal during 1972-79. Trop. Octan-Almos. Newsi. 30. pp. 15-16. 105:

Kishino. M.. Energy balance of underwater radiation rejatec to marine photosynthesis. in Biological and Chemical Utilizarion of Solar Entrgy, ediled by K. Sh:bata, A. Iwarrura, and A. Ikegami, pp. 59-69. Japan Scientific Societies Press. Tokyo. 1981.

Lampi:. R. S. Evidence for the seasonal deposition of detritus to the deep-sea foor and its subsequent resuspension. Deen Sea Res., 32(8), 885-897. 1985 .

Legendre, $L$.. The significance of microalgal blooms for fisheries and for the export of particulate organic carbon in the oceans. $J$. Plankion Res., 12(4), 681-695. 1990

Lenz. J.. Particulate organic matter off northwest Africa: Size distribution and composition in relation to shore distance and depth. Rapp P V Reun. Cons. Int. Explor. Mar. 180. 234-238. 198 ?.

Longhurst, A. R., and W. G. Harrison. The biological pump: Profiles of plankton production and consumption in the upper occan. Prog. Oceanogr., 22, 47-123. 1989.

Malone, T. C.. Environmental control of phytoplankton cell size. Limnol. Oceanogr. 20, 495. 1975.

Martin, J. H., G. A. Knauer, D. M. Kar!, and W', W. Broenkow, VERTEX: Carbon cycling in the northeas: Pacific. Deup Sca Res., 34, 267-285, 1987.

NicClair. C. R. S. Chao. L. P. Atkinson. J. O. Blanton, and F. De Castillejo. Wind-driven upwelling in the vicinily of Cape Finisterre, Spain. J. Giophrs. Rex.. 9/(C7), 8470-8486, 1986.

McClain, C. R.. W'. E. Esaias, G. C. Feldman. J. Elrod. D. Endres. J. Firestone. M. Darzi, R. Evans, ard J. Brown, Physical and biological processes in the North Atlantic during the First GARP Global Experiment, J. Grophys. Res., 95(C10), 18.027-18.048, 1990.

Meincke, J., S. Mittelstaedt, K. Huber, and K. P. Koltermann Currents and stratification in the upwelling area of the northwest Africa. Disch. Hydrogr. Meerskd. Beobachungen Ergeh. 41, 117 pp., 1975.

Minas, H. J., L. A. Codisnoti, and R. C. Dugdale. Nutrients and primary production in the upwelling region off northwest Africa, Rapp. PY. Rew Cons. Int. Expler. Mer., 180, 148-183. 1982a

Minas. H. J., T. T. Packard. M. Minas, and B. Coske. An analysis of the production-regeneration system in the coastat upuelling area of NW Airical based on oxygen. nitrate and ammonium distributions. J. Mar. Res.. 40,615-641. 1982b.

Mittelstaedt. E.. Large-scale circulation along the coast of north. wes: Africa. Rapr. P l'. Roum. Cons. Int. Erplor. Mer., 180. 50-57. 1982.

Mitlelstaedt. E.. The ocean boundary along the nor:hwest African coast: Circulation and occanogranhic properties at the sea surface, Prog. Oceanugr.. 26, 307-355. 1991.

Mittelstaedt. E., D. Pillsbury and R. L. Smith. Flow patterns in the northuest African upueiling area. Results of meilsurements along $21^{\circ} 40 \times N$ during February-April 1974. JOINT-I. Dirc/l. Hudrogr. Z., $28,145-16 \%, 1975$

Morel, A. Optical properties and radiant energy in the waters of the Guinea Dome and the Mauritanian upwelline area in relation to primary productoon. Rupn. P I. Re'un. Coms Int. Evelur. Mer. $180,94-107.198 ?$

Norel. A.. and ¿.F. Berthon. Surface piements, algal biomass profiles and potential production of the euphotic laver. Reiation. ships rernvestigated on view of remote sensing applications. Lim. nol. Oceanuer $3+181,155-1563,1989$

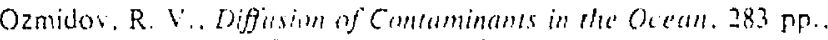
Koluwer Academic. Boston. Mass.. 199i).

Rowe. G. T., S. Smith, P. Falkowski. T. Whisledge. R. Theroux, W Proel. and $H$ Duckluu. Do continential shelves export oristini: matter'. Viaturt. 324.559-561, 1986.

Seibold. E., Sediments in upuelling areas, pitricularly off northwest

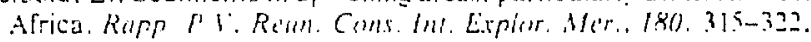
:982.

Smetacek. V. S. Role of stnkine in dialom life-hustory cycles: 
Ecological, evolutionary and geological significance, Mar. Biol., 84. 239-251, 1985 .

Smith, D. J., G. Eglinton, and R. J, Morris, Interfacial sediment and assessment of organic input from a highly productive water column, Nature, 304, 259-262, 1983.

Smith, R. C., Remote sensing and the depth distribution of ocean chlorophyll, Mar. Ecol., 5, 359-361, 1981.

Smith, W. O., G. W. Hebum, R. T. Barber, and J. J, O'Brien. Regulation of phytoplankion communities by physical processes in upwelling systems, J. Mar. Res., 41, 539-556, 1983.

Speth, P., and H. Detlefsen, Meteorological influences on upwelling off northwest Africa, Rapp. $P$ V' Reun. Cons. Int. Fxplor. Mer. 180, 29-34, 1982.

Sturm. B., Selected topics of coastal zone color scanner evaluation. in Remote Sensing Applicalions in Marine Science and Technology, edited by A. P. Cracknell, pp. 137-168, D. Reidel. Norwell, Mass., 1983.

Takahashi, T., J. Goddard, S. Sutherland, D. W. Chipman, and C. C. Breeze, Seasonal and geographic variability of carbon dioxide sink/source in the oceanic areas: Observations in the north and equatorial Pacific Ocean, 1984-1986 and global summary, DOE Tech. Rep. MRETTA 19X-89675C, pp. 1-52, U.S. Dep. of Energy, Washington, D. C., 1986

Tomczak, M., Jr., The distribution of water masses at the surface as derived from $T \cdot S$ diagram analysis in the CINECA area. Rapp. $P$ V. Reun. Cons. Im. Explor. Mer., 180, 48-49, 1982.

Van Camp, L., L. Nykjaer, E. Mittelstaedt, and P. Schlittenhardt, Upwelling and boundary circulation off northwest Africa as depicted by infrared and visible satellite observations, Prog. Oceanogr., 26, 357-402, 1991.

Walsh, J. J., Death in the sea: Enigmatic phytoplankton losses, Prog. Oceanogr., 12, 1-86, 1983.

Walsh, J. J., How much shelf production reaches the deep sea, in
Productivity of the Ocean: Present and Past, edited by W. H. Berger. V. S. Smetacek, and $G$. Wefer, pp. 175-191, John Wiley, New York, 1989.

Walsh. J. J., G. T. Rowe, R. L. Iverson, and C. P. McRoy, Biological export of shelf carbon is a sink of the global $\mathrm{CO}_{2}$ cycle. Nature. 291, 196-201, 1981.

Weiker, H., Some features of zooplankton distribution in the upper $200 \mathrm{~m}$ in the upwelling region off northwest Africa, Rapp. $P V$. Reun. Cons. Int. Explor. Mer., 180, 280-288, 198 ?.

Wilkerson, F. P., and R. C. Dugdale. The use of large shipboard barrels and drifters to study the effects of coastal upuelling on phytoplankton dynamics, Limnol. Oceanogr., 32, 368-382. 1987. Wollast, R., The coastal organic carbon cycle: Fluxes, sources and sinks, paper presented at Dahlem Workshop on Ocean Margin Processes in Global Change, Berlin. March, 1990.

Wooster, W. S., A. Bakun, and D. R. McLain, The seasonal upwelling cycle along the eastern boundary of the North Atlantic. J. Mar. Res., 34, 131-141, 1976.

Wroblewski, J. S., A model of phytoplankton plume formation during variable Oregon upwelling. J. Mar. Res., 35. 357-394, 1977.

W. Eifler, L. Garcia, L. Nykjaer, W. Schrimpf, and L, Van Camp. Institute for Remote Sensing Applications, Joint Research Centre, Ispra Site, I-21020 Ispra, Italy.

A. J. Gabric, Faculty of Environmental Sciences, Griffith University, Nathan Campus, Kessels Road, Brisbane, Queensland 4111, Australia. 